\title{
PENGARUH METODE PENGERINGAN TERHADAP MUTU SIMPLISIA DAUN PULUTAN (Urena lobata L.)
}

\section{THE EFFECT OF DRYING METHOD ON THE QUALITY OF LEAF SIMPLISIA PULUTAN (Urena lobata L.)}

\author{
Nizar Fahmi ${ }^{1}$, Irvan Herdiana ${ }^{2}$, Rani Rubiyanti ${ }^{3 *}$ \\ ${ }^{1}$ Poltekkes Kemenkes Tasikmalaya, email: zarfahmi25@gmail.com \\ ${ }^{2}$ Poltekkes Kemenkes Tasikmalaya, email: tvirus2588@gmail.com \\ ${ }^{3}$ Poltekkes Kemenkes Tasikmalaya, email: rani.rubiyanti@yahoo.co.id*
}

\begin{abstract}
ABSTRAK
Pengeringan merupakan salah satu proses pasca panen yang berperan penting terhadap mutu simplisia. Tujuan penelitian ini yaitu untuk mengetahui pengaruh metode pengeringan terhadap mutu simplisia daun pulutan (Urena lobata L.). Metode penelitian ini yaitu eksperimental laboratorium dengan menggunakan metode pengeringan sinar matahari langsung, metode pengeringan sinar matahari ditutupi kain hitam, metode oven dengan variasi suhu $45^{\circ} \mathrm{C}, 50^{\circ} \mathrm{C}$, $60^{\circ} \mathrm{C}$. Analisis yang digunakan pada penelitian ini yaitu analisis deksriptif yang ditampilkan dalam bentuk tabel untuk hasil pengamatan organoleptik, makroskopik dan kromatografi lapis tipis (KLT). Hasil menunjukan bahwa metode pengeringan berpengaruh terhadap mutu simplisia daun pulutan. Pengeringan menggunakan oven dengan variasi suhu $45^{\circ} \mathrm{C}$ dan $50^{\circ} \mathrm{C}$ merupakan pengeringan yang baik karena didapat hasil warna daun hijau cerah, tidak berasa, bau khas daun pulutan, daun berbentuk menjari, tepi daun bergerigi, berbulu halus dibagian daun, rapuh saat digenggam, terdapat jaringan khas dan hasil KLT menunjukan adanya kandungan senyawa flavonoid.
\end{abstract}

Kata Kunci : Urena lobata L., pengeringan, mutu simplisia.

\begin{abstract}
Drying is one of the post-harvest processes that plays an important role in the quality of simpliciaThe purpose of this reaserch is to know the effect of drying method on the quality of the leaves pulutan simplicia (Urena lobata L.). This research method is experimental laboratory using direct sunlight drying method, sun drying is covered by black cloth method, oven method with a variation of temperature of $45{ }^{\circ} \mathrm{C}, 50{ }^{\circ} \mathrm{C}, 60{ }^{\circ} \mathrm{C}$. The analysis used in this study is descriptive analysis that is displayed in the form of tables for observations of organoleptic, macroscopic and thin layer chromatography (TLC). The results showed that the drying method affected the quality of pulutan leaf simplicia. Drying using an oven with a temperature variation of $45{ }^{\circ} \mathrm{C}$ and $50{ }^{\circ} \mathrm{C}$ is a good drying because it gets the results of bright green leaves, tasteless, distinctive smell of pulutan leaves, runny leaves, jagged leaf edges, downy leaves, brittle when held, there is tissue typical and results of TLC show the presence of compounds flavonoid.
\end{abstract}

Keywords: Urena lobata L., drying, simplicia quality.

\section{PENDAHULUAN}

Daun pulutan tumbuh di daerah beriklim tropik seperti di Indonesia. Pulutan termasuk ke dalam tumbuhan suku kapas-kapasan
(Malvaceae). Seperti yang telah diketahui, pulutan mengandung flavonoid yang memiliki aktivitas antioksidan dan digunakan sebagai obat antidiabetes, antibakteri, dan antifungi. ${ }^{1}$ 
Dalam bidang pengobatan herbal, daun pulutan sering digunakan untuk obat diabetes. Pemanfaatan daun pulutan di masyarakat hanya digunakan dalam bentuk rebusan saja, sehingga perlu dibuat inovasi dalam bentuk lain seperti dibuat dalam keadaan kering. ${ }^{2}$ Tumbuhan obat biasa dibuat dalam bentuk kering atau sering disebut simplisia. Kualitas simplisia dipengaruhi beberapa faktor, salah satunya yaitu proses pengeringan. Pembuatan simplisia dengan cara pengeringan harus dilakukan dengan cepat tetapi pada suhu yang tidak terlalu tinggi. Pengeringan dengan waktu yang lama juga akan mengakibatkan mutu simplisia yang kurang baik, dikarenakan kandungan metabolit yang terdapat dalam tumbuhan memiliki kepekaan yang berbeda terhadap proses pengeringan. ${ }^{3}$

Pengeringan merupakan salah satu proses pasca panen yang berperan penting terhadap mutu simplisia ${ }^{4}$. Terdapat berbagai macam metode yang dilakukan dalam pengeringan, seperti pengeringan menggunakan sinar matahari langsung, pengeringan menggunakan sinar matahari ditutup dengan kain hitam dan pengeringan menggunakan oven. Untuk pengeringan sinar matahari ditutup dengan kain hitam dan pengeringan langsung menggunakan sinar matahari merupakan pengeringan yang paling ekonomis dan mudah dilakukan dikarenakan tidak memerlukan metode khusus serta alat yang banyak, akan tetapi metode tersebut tidak dapat dilakukan pada saat cuaca hujan dan dalam keadaan malam hari. Pengeringan menggunakan oven dengan suhu teratur menguntungkan karena akan terjadi pengurangan kadar air yang signifikan dalam waktu yang relatif singkat. $^{5}$

Kandungan metabolit sekunder pada tumbuhan dipengaruhi oleh proses pengeringan. Pengeringan yang tepat akan menghasilkan mutu simplisia yang baik sehingga tahan disimpan untuk waktu yang lama dan tidak terjadi perubahan bahan aktif yang dikandungnya ${ }^{1}$. Berdasarkan pernyataan di atas maka akan dilakukan penelitian untuk mengetahui pengaruh beberapa cara pengeringan terhadap mutu simplisia daun pulutan (Urena lobata L). Parameter yang diukur adalah organoleptik, makroskopik, mikroskopik dan kromatografi lapis tipis (KLT) .

\section{METODE}

Metode penelitian ini yaitu eksperimental laboratorium dengan sampel daun pulutan berasal dari Desa Ciketak Kecamatan Kadugede Kabupaten Kuningan Provinsi Jawa Barat dengan no.Determinasi 338/UN58.01.6/LL/2019. Pengeringan menggunakan metode pengeringan matahari langsung, metode pengeringan dengan sinar matahari langsung ditutup menggunakan kain hitam dan pengeringan menggunakan metode oven dengan variasi suhu $45^{\circ} \mathrm{C}, 50^{\circ} \mathrm{C}, 60^{\circ} \mathrm{C}$.

\section{Prosedur pembuatan}

1. Penyiapan Bahan Penelitian

Pengambilan sampel dilakukan dengan cara dipilih daun yang terletak di bagian cabang batang yang menerima sinar matahari langsung. Sampel diambil menggunakan tangan atau menggunakan alat yang tidak mengandung logam, dikarenakan berpotensi terjadinya reaksi dengan logam tersebut sehingga dapat merusak sampel atau kandungan metabolit sekunder yang terkandung di dalamnya. ${ }^{4}$

Bahan sampel yang telah dikumpulkan kemudian disimpan di dalam wadah yang bukan terbuat dari logam. Pilih daun yang mulus dan tidak terdapat cacat sedikitpun. Daun yang baik tidak terdapat cacat, kotoran, debu, ulat, rusak atau benda asing lain. ${ }^{3}$ Pencucian dilakukan untuk menghilangkan bahan pengotor lainnya yang melekat pada simplisia. Pencucian dilakukan dengan menggunakan air bersih yang mengalir sampai daun benar-benar terbebas dari kotoran maupun benda asing. ${ }^{3}$

Perajangan dilakukan menggunakan pisau dan diberi alas sebelum dilakukan pemotongan, pemotongan bahan simplisia harus sama ukurannya. Bahan simplisia yang telah dirajang dengan 
ukuran yang sama dimaksudkan untuk membantu mempercepat proses pengeringan. ${ }^{3}$

\section{Metode Pengeringan}

Pengeringan dengan sinar matahari langsung dan pengeringan dengan ditutupi kain hitam dilakukan selama 48 jam, tergantung dari keadaan cuaca. Pengeringan menggunakan oven dilakukan selama 6 sampai 8 jam. ${ }^{3}$

a. Pengeringan dengan sinar matahari langsung

Bahan simplisia yang telah dirajang kemudian ditimbang sebanyak $300 \mathrm{~g}$, wadah yang digunakan untuk pengeringan tersebut mempunyai dasar yang berlubang-lubang seperti anyaman bambu dimaksudkan agar aliran udara dari atas ke bawah atau sebaliknya berjalan lancar.

b. Pengeringan dengan ditutupi kain hitam menggunakan bantuan sinar matahari langsung

Bahan simplisia yang telah dirajang kemudian ditimbang sebanyak $300 \mathrm{~g}$, wadah yang digunakan untuk pengeringan tersebut mempunyai dasar yang berlubang-lubang seperti anyaman bambu dimaksudkan agar aliran udara dari atas ke bawah atau sebaliknya berjalan lancar. Setelah itu ditutup bagian atasnya menggunakan kain hitam kemudian langsung dijemur.

c. Pengeringan menggunakan oven

Bahan yang telah dirajang kemudian ditimbang sebanyak $300 \mathrm{~g}$ untuk masing-masing variasi suhu, bahan simplisia kemudian dimasukan kedalam oven, atur suhu sesuai dengan metode uji yaitu pada suhu $45^{\circ} \mathrm{C}$, suhu $50^{\circ} \mathrm{C}$, dan suhu $60^{\circ} \mathrm{C}$.

3. Pemeriksaan Mutu Simplisia Daun Pulutan

Pengujian mutu yang dilakukan pada simplisia daun pulutan (Urena lobata L.) adalah sebagai berikut :

a.Organoleptik

Penggunaan panca indera mendeksripsikan bentuk, warna, bau dan rasa ${ }^{4}$. b. Makroskopik

Penggunaan panca indera dengan bantuan alat kaca pembesar untuk mengamati ciri-ciri luar simplisia meliputi bentuk morfologi dan tekstur. ${ }^{4}$

c. Mikroskopik

Penggunaan panca indera dengan bantuan alat mikroskop untuk mengamati anatomi jaringan yang khas dari simplisia tersebut. $^{4}$

d. Kromatografi lapis tipis (KLT)

Pengujian dilakukan menggunakan simplisia kering kemudian dilakukan proses ektraksi dipercepat menggunakan etanol $70 \%$ lalu dipanaskan sampai mendidih. Eluen yang digunakan yaitu nbutanol : asam asetat : aquadest dengan perbandingan $9: 2: 6(\mathrm{v} / \mathrm{v})$ atau BAA. ${ }^{6}$

\section{HASIL}

\section{A. Uji Simplisia}

Tabel 1. Hasil Uji Organoleptik

\begin{tabular}{|c|c|c|c|c|c|c|}
\hline \multirow{2}{*}{$\begin{array}{l}\text { Orga- } \\
\text { nolep- } \\
\text { tik }\end{array}$} & \multicolumn{2}{|c|}{ Sinar Matahari } & \multicolumn{3}{|c|}{ Oven } & \multirow{2}{*}{$\begin{array}{c}\text { Kontrol } \\
\text { Diangin- } \\
\text { angin }\end{array}$} \\
\hline & $\begin{array}{l}\text { Lang- } \\
\text { sung }\end{array}$ & $\begin{array}{c}\text { Ditutup } \\
\text { Kain } \\
\text { Hitam }\end{array}$ & $\begin{array}{l}\text { Suhu } \\
45^{\circ} \mathrm{C}\end{array}$ & $\begin{array}{l}\text { Suhu } \\
50^{\circ} \mathrm{C}\end{array}$ & $\begin{array}{l}\text { Suhu } \\
60^{\circ} \mathrm{C}\end{array}$ & \\
\hline Warna & $\begin{array}{l}\text { Hijau } \\
\text { kehi- } \\
\text { taman }\end{array}$ & $\begin{array}{l}\text { Hijau } \\
\text { kecoklat- } \\
\text { an }\end{array}$ & $\begin{array}{l}\text { Hijau } \\
\text { cerah }\end{array}$ & $\begin{array}{l}\text { Hijau } \\
\text { cerah }\end{array}$ & $\begin{array}{l}\text { Hijau } \\
\text { kecok- } \\
\text { latan }\end{array}$ & $\begin{array}{l}\text { Hijau } \\
\text { kecoklat- } \\
\text { an }\end{array}$ \\
\hline Rasa & $\begin{array}{l}\text { Tidak } \\
\text { Berasa }\end{array}$ & $\begin{array}{l}\text { Tidak } \\
\text { Berasa }\end{array}$ & $\begin{array}{l}\text { Tidak } \\
\text { Berasa }\end{array}$ & $\begin{array}{l}\text { Tidak } \\
\text { berasa }\end{array}$ & $\begin{array}{l}\text { Tidak } \\
\text { berasa }\end{array}$ & $\begin{array}{l}\text { Tidak } \\
\text { berasa }\end{array}$ \\
\hline Bau & $\begin{array}{l}\text { Bau } \\
\text { khas } \\
\text { daun } \\
\text { pulutan }\end{array}$ & $\begin{array}{l}\text { Bau khas } \\
\text { daun } \\
\text { pulutan }\end{array}$ & $\begin{array}{l}\text { Bau } \\
\text { khas } \\
\text { daun } \\
\text { pulutan }\end{array}$ & $\begin{array}{l}\text { Bau } \\
\text { khas } \\
\text { daun } \\
\text { pulutan }\end{array}$ & $\begin{array}{l}\text { Bau } \\
\text { khas } \\
\text { daun } \\
\text { pulutan }\end{array}$ & $\begin{array}{l}\text { Bau khas } \\
\text { daun } \\
\text { pulutan }\end{array}$ \\
\hline
\end{tabular}

B. Uji Makroskopik

Tabel 2. Hasil Uji Makroskopik

\begin{tabular}{|c|c|c|c|c|c|c|}
\hline \multirow{2}{*}{$\begin{array}{l}\text { Makro- } \\
\text { skopik }\end{array}$} & \multicolumn{2}{|c|}{ Sinar Matahari } & \multicolumn{3}{|c|}{ Oven } & \multirow{2}{*}{$\begin{array}{c}\text { Kontrol } \\
\text { Diangin- } \\
\text { angin }\end{array}$} \\
\hline & $\begin{array}{l}\text { Lang- } \\
\text { sung }\end{array}$ & $\begin{array}{c}\text { Ditutup } \\
\text { Kain } \\
\text { Hitam }\end{array}$ & $\begin{array}{l}\text { Suhu } \\
45^{\circ} \mathrm{C}\end{array}$ & $\begin{array}{l}\text { Suhu } \\
50^{\circ} \mathrm{C}\end{array}$ & $\begin{array}{l}\text { Suhu } \\
60^{\circ} \mathrm{C}\end{array}$ & \\
\hline $\begin{array}{l}\text { Bentuk } \\
\text { morfolo } \\
\text { gi }\end{array}$ & $\begin{array}{l}\text { Tepi } \\
\text { daun } \\
\text { bergeri- } \\
\text { gi dan } \\
\text { berbulu } \\
\text { halus } \\
\text { dibagi- } \\
\text { an daun }\end{array}$ & $\begin{array}{l}\text { Tepi daun } \\
\text { bergerigi } \\
\text { dan } \\
\text { berbulu } \\
\text { halus } \\
\text { dibagian } \\
\text { daun }\end{array}$ & $\begin{array}{l}\text { Tepi } \\
\text { daun } \\
\text { bergeri- } \\
\text { gi dan } \\
\text { berbulu } \\
\text { halus } \\
\text { dibagi- } \\
\text { an daun }\end{array}$ & $\begin{array}{l}\text { Tepi } \\
\text { daun } \\
\text { bergeri- } \\
\text { gi dan } \\
\text { berbulu } \\
\text { halus } \\
\text { dibagi- } \\
\text { an daun }\end{array}$ & $\begin{array}{l}\text { Tepi } \\
\text { daun } \\
\text { bergeri } \\
\text { gi dan } \\
\text { berbulu } \\
\text { halus } \\
\text { dibagi- } \\
\text { an } \\
\text { daun }\end{array}$ & $\begin{array}{l}\text { Tepi daun } \\
\text { bergerigi } \\
\text { dan } \\
\text { berbulu } \\
\text { halus } \\
\text { dibagian } \\
\text { daun }\end{array}$ \\
\hline Tekstur & $\begin{array}{l}\text { Rapuh } \\
\text { saat } \\
\text { digeng- } \\
\text { gam }\end{array}$ & $\begin{array}{l}\text { Sedikit } \\
\text { basah } \\
\text { saat } \\
\text { digeng- } \\
\text { gam }\end{array}$ & $\begin{array}{l}\text { Rapuh } \\
\text { saat } \\
\text { digeng- } \\
\text { gam }\end{array}$ & $\begin{array}{l}\text { Rapuh } \\
\text { saat } \\
\text { digeng- } \\
\text { gam }\end{array}$ & $\begin{array}{l}\text { Rapuh } \\
\text { saat } \\
\text { digeng } \\
\text { gam }\end{array}$ & $\begin{array}{l}\text { Sedikit } \\
\text { basah saat } \\
\text { digenggam }\end{array}$ \\
\hline
\end{tabular}


C. Uji Mikroskopik

Tabel 3. Hasil Uji Mikroskopik

\begin{tabular}{llllll}
\hline \multicolumn{2}{c}{ Sinar matahari } & & Oven & Kontrol \\
\hline Langsung & $\begin{array}{c}\text { Ditutup } \\
\text { kain hitam }\end{array}$ & Suhu $45^{\circ} \mathrm{C}$ & Suhu $50^{\circ} \mathrm{C}$ & $\begin{array}{c}\text { Suhu } \\
60^{\circ} \mathrm{C}\end{array}$ & $\begin{array}{c}\text { Diangin- } \\
\text { angin }\end{array}$ \\
\hline & & & &
\end{tabular}

D. Uji Kromatografi Lapis Tipis

Tabel 4. Hasil Uji KLT

\begin{tabular}{lll}
\hline \multicolumn{1}{c}{$\begin{array}{c}\text { Metode } \\
\text { Pengeringan }\end{array}$} & $\begin{array}{c}\text { Warna } \\
\text { noda }\end{array}$ & Nilai Rf \\
\hline $\begin{array}{l}\text { Sinar matahari } \\
\text { Kain hitam }\end{array}$ & $\begin{array}{l}\text { Kuning } \\
\text { Kuning }\end{array}$ & 0,61 \\
$\begin{array}{l}\text { Oven dengan suhu } \\
45^{\circ} \mathrm{C}\end{array}$ & $\begin{array}{c}\text { Kuning } \\
\text { Oven dengan suhu }\end{array}$ & 0,64 \\
$50^{\circ} \mathrm{C}$ & Kuning & 0,64 \\
$\begin{array}{l}\text { Oven dengan suhu } \\
60^{\circ} \mathrm{C}\end{array}$ & Kuning & 0,64 \\
Diangin-angin & Kuning & 0,62 \\
\hline
\end{tabular}

\section{PEMBAHASAN}

\section{A. Hasil Uji Organoleptik}

Sebelum dilakukan proses pengeringan, warna daun pulutan hijau cerah. Setelah dilakukan proses pengeringan didapat perbedaan warna signifikan pada daun. Perbedaan terlihat pada pengeringan menggunakan sinar matahari langsung, pengeringan sinar matahari yang ditutup ditutup kain hitam, pengeringan dengan oven suhu $60^{\circ} \mathrm{C}$ dan diangin-angin, warna daun menjadi hijau kehitam-hitaman dan kecoklatan. Sedangkan pengeringan menggunakan metode oven dengan variasi suhu $45^{\circ} \mathrm{C}$ dan $50^{\circ} \mathrm{C}$ mempunyai warna hijau cerah. Berubahnya warna daun disebabkan oleh terjadinya degradasi klorofil yang berwarna hijau menjadi hijau kehitam-hitamanan dan hijau kecoklatan selama proses pengeringan, salah satu sifat terpenting klorofil adalah kelabilan yang sensitif terhadap cahaya, suhu, panas dan oksigen. Selain itu air yang masih tersisa dalam simplisia pada kadar tertentu merupakan media pertumbuhan kapang serta enzim tertentu dalam sel masih dapat bekerja menguraikan senyawa aktif sesaat setelah sel mati dan selama simplisia tersebut masih mengandung kadar air. Pada tumbuhan yang masih hidup, pertumbuhan kapang dan reaksi enzimatik yang merusak itu tidak terjadi karena adanya keseimbangan antara proses metabolisme seperti fotosintesis, transformasi dan penggunaan isi sel. ${ }^{3}$

B. Hasil Uji Makroskopik

Pengamatan yang dilakukan pada pengujian makroskopik didapat perbedaan dari segi tekstur simplisia daun pulutan. Pengeringan dengan metode kain hitam dan diangin-angin tekstur daun sedikit basah apabila digenggam. Hal ini diakibatkan karena pada metode pengeringan langsung menggunakan kain hitam dan pengeringan dengan diangin-angin pengeringanya tidak terlalu panas sehingga memerlukan waktu relatif lama dibandingkan dengan metode pengeringan lain. Semakin tinggi suhu dan aliran udara pengeringan semakin cepat pula proses pengeringan berlangsung. Semakin tinggi suhu udara pengering, semakin besar energi panas yang dibawa udara sehingga semakin banyak jumlah masa cairan yang diuapkan dari permukaan bahan yang dikeringkan. ${ }^{7}$

C. Hasil Uji Mikroskopik

Hasil pengujian mikroskopik pada simplisia daun pulutan berupa jaringan khas yang membedakan dari tumbuhan lain. Daun pulutan mempunyai jaringan khas yaitu fragmen rambut penutup berbentuk bintang, berkas pembuluh dan kalsium oksalat berbentuk roset ${ }^{8}$. Pada pengujian mikroskopik dengan metode pengeringan sinar matahari langsung, pengeringan yang ditutupi kain hitam dan pengeringan menggunakan oven dengan variasi suhu $45^{\circ} \mathrm{C}, 50^{\circ} \mathrm{C}, 60^{\circ} \mathrm{C}$ terdapat fragmen rambut penutup berbentuk bintang, berkas pembuluh dan hablur 
kalsium oksalat berbentuk roset. Hal ini sesuai dengan pustaka acuan.

D. Hasil Uji Kromatografi Lapis Tipis Kromatografi lapis tipis dilakukan untuk pengujian kandungan senyawa yang terdapat pada simplisia daun pulutan. Senyawa yang akan diidentifikasi pada pengujian kromatografi lapis tipis yaitu flavonoid. Eluen yang digunakan yaitu nbutanol, asam asetat glasial, aqua destilata dengan perbandingan 9: 2 :6 $\mathrm{v} / \mathrm{v}$ dalam $6 \mathrm{ml}^{6}$. Plat kromatografi yang dipakai berukuran $8 \times 4 \mathrm{~cm}$ dengan garis tepi $1 \mathrm{~cm}$. Noda yang didapat pada pengujian kromatografi lapis tipis terdapat noda berwarna kuning. Senyawa flavonoid menunjukan zat warna hijau atau kuning pada plat kromatografi. Nilai $\mathrm{Rf}$ yang diperoleh setelah dihitung tidak menunjukan perbedaan nilai yang signifikan antara masing-masing metode pengeringan yang dilakukan sehingga dapat disimpulkan metode pengeringan tidak mempengaruhi kandungan senyawa flavonoid pada simplisia daun pulutan.

\section{SIMPULAN DAN SARAN}

Metode pengeringan berpengaruh terhadap mutu simplisia daun pulutan. Pengeringan menggunakan oven dengan variasi suhu $45^{\circ} \mathrm{C}$ dan $50^{\circ} \mathrm{C}$ merupakan pengeringan yang baik karena didapat hasil warna daun hijau cerah, tidak berasa, bau khas daun pulutan, daun berbentuk menjari, tepi daun bergerigi, berbulu halus dibagian daun, rapuh saat digenggam, terdapat jaringan khas dan hasil KLT menunjukan adanya kandungan senyawa flavonoid dan perlu adanya penelitian lebih lanjut mengenaikandungan senyawa pada masing-masing simplisia dengan pengeringan berbeda tersebut.

\section{DAFTAR PUSTAKA}

1. Dixa S, Singh V.S. Isolation and Characterization of Flavonoids in Urena lobata L. Eurpean Journal of Medicinal Plants, Vol. 1. 2016. hal 16.
2. Fagbohun E.D, Asare R.R, Egbebi A.O. Chemical Composition and Antimicrobial Activities of Urena lobata L. Journal of Medicinal Plants Reserch Vol. 6. 2012

3. Prasetyo, Inoriyah E.Pengelolaan Budidaya Tanaman Obat-obatan (Bahan Simplisia). Bengkulu: Badan Penerbitan Fakultas Pertanian UNIB; 2013

4. Depkes RI. Cara Pembuatan Simplisia. Departemen Kesehatan Republik Indonesia. Jakarta: DEPKES; 1985.

5. Muller J, Heindl. Drying Of Medical Plants In R.J. Bogers, L.E.Cracer, and Lange D, (eds). Medical and Aromatic Plant. The Netherland: Springer. 2006. p.237-252.

6. Rohyami Y, Identifikasi Flavonoid dari Ekstrak Metanol Daging Buah Mahkota Dewa (Phaleria macrocarpa Boerl) Menggunakan Spektrofotometer UV-Vis dan FT-IR, Laporan Penelitian PDM DIKTI. 2008.

7. Rachmawan O. Pengeringan, Pendinginan dan Pengemasan Komoditas Pertanian. Buletin Departemen Pendidikan Nasional. Jakarta: 2001.

8. Nurhasanah T. Lukmayani Y. Kodir R.A. Karakterisasi Simplisia dan Ekstrak Serta Identifikkasi Histokimia Daun Pulutan (Urena lobata L.). Jurnal Farmasi Prodi Farmasi, Fakultas Matematika dan IImu Pengetahuan Alam. Universitas Islam Bandung, Vol. 5, No. 1. 2019.

9. Markham K.R. Cara Mengidentifikasi Flavonoid. Terjemahan Kosasih Padmawinata. Bandung: Badan Penerbit Institut Teknologi Bandung; 1988. 